\title{
A Case Study of a Plant-Animal Relationship: Cola lizae and Lowland Gorillas in the Lope Reserve, Gabon
}

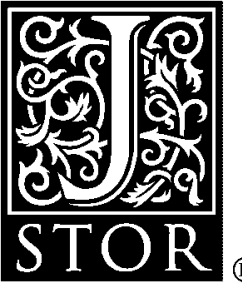

\author{
Caroline E. G. Tutin; Elizabeth A. Williamson; M. Elizabeth Rogers; Michel Fernandez
}

Journal of Tropical Ecology, Vol. 7, No. 2. (May, 1991), pp. 181-199.

Stable URL:

http://links.jstor.org/sici?sici=0266-4674\%28199105\%297\%3A2\%3C181\%3AACSOAP\%3E2.0.CO\%3B2-N

Journal of Tropical Ecology is currently published by Cambridge University Press.

Your use of the JSTOR archive indicates your acceptance of JSTOR's Terms and Conditions of Use, available at http://www.jstor.org/about/terms.html. JSTOR's Terms and Conditions of Use provides, in part, that unless you have obtained prior permission, you may not download an entire issue of a journal or multiple copies of articles, and you may use content in the JSTOR archive only for your personal, non-commercial use.

Please contact the publisher regarding any further use of this work. Publisher contact information may be obtained at http://www.jstor.org/journals/cup.html.

Each copy of any part of a JSTOR transmission must contain the same copyright notice that appears on the screen or printed page of such transmission.

The JSTOR Archive is a trusted digital repository providing for long-term preservation and access to leading academic journals and scholarly literature from around the world. The Archive is supported by libraries, scholarly societies, publishers, and foundations. It is an initiative of JSTOR, a not-for-profit organization with a mission to help the scholarly community take advantage of advances in technology. For more information regarding JSTOR, please contact support@ jstor.org. 


\title{
A case study of a plant-animal relationship: Cola lizae and lowland gorillas in the Lopé Reserve, Gabon
}

\author{
CAROLINE E. G. TUTIN ${ }^{1}$; ELIZABETH A. WILLIAMSON ${ }^{2}$, \\ M. ELIZABETH ROGERS ${ }^{3}$ and MICHEL FERNANDEZ ${ }^{1}$
}

Centre International de Recherches Médicales de Franceville, BP 769, Franceville, Gabon.

${ }^{1}$ C.I.R.M.F. and Department of Psychology, University of Stirling, Scotland.

${ }^{2}$ Department of Psychology, University of Stirling, Scotland.

${ }^{3}$ Department of Zoology, University of Edinburgh, Scotland.

\begin{abstract}
The fruits of Cola lizae, an endemic tree with a limited geographical distribution, have been a major food source for lowland gorillas in the Lopé Reserve during part of each year over a six-year period. Faecal analysis indicated that $11,000-18,000$ Cola seeds $\mathrm{km}^{-2}$ were deposited by gorillas during the 4-month season in 1989. Gorillas are the only important dispersers of this species: other primates consume the succulent mesocarp, but do not swallow the large seed; elephants do not eat Cola fruits. Observations of Cola seeds in gorilla faeces showed a very high germination rate and, despite initial high mortality, $18 \%$ of seedlings still survived six months after deposition. Survival of seedlings was significantly better in faeces left at nest-sites than in other areas of the forest: $40 \%$ of seedlings were viable at nest-sites six months after deposition. This suggests that the open areas of forest, preferred by gorillas as nest-sites, are advantageous to the propagation of this species.
\end{abstract}

KEY WORDS: Cola, frugivory, Gabon, lowland gorilla, Gorilla g. gorilla, plant-animal interactions, seed dispersal, seedling survival.

\section{INTRODUCTION}

The role of primates in the dispersal of seeds has been described at length (e.g. Estrada \& Coates-Estrada 1984, 1986, Garber 1986, Gautier-Hion 1984, Hladik \& Hladik 1967, Howe 1980, Lieberman et al. 1979), and has been noted for all species of great apes except gorillas (bonobos: Idani 1986; chimpanzees: Takasaki 1983; orang-utans: Galdikas 1982). An ongoing long-term study of western lowland gorillas (Gorilla gorilla gorilla Savage \& Wyman 1847) in Gabon has demonstrated that this subspecies is frugivorous (Tutin \& Fernandez 1985, Williamson et al. 1990). Definitions of frugivory vary and quantitative data on the diet of lowland gorillas are not yet available but, at the Lopé, gorillas eat fruit of at least 78 species and the remains of at least one species of fruit were found in $97 \%$ of gorilla faeces (Tutin \& Fernandez 1987). Seedlings of several 
tree species have been seen sprouting in gorilla dung (e.g. Celtis tessmannii Rendle, Parkia bicolor A. Chev., Santiria trimera (Oliv.) Aubr.). Their large body and gut size, together with the considerable quantities of seeds they swallow, make gorillas potentially important dispersal agents for most of the species whose fruits they eat.

This paper concentrates on the relationship between gorillas at the Lopé and one species of tree, Cola lizae (N. Hallé 1987), a Sterculiaceae, which is of special interest for three main reasons: 1) in terms of density and dominance (basal area), Cola lizae is the most important tree in the Lopé study area (Williamson 1988) and, as such, is significant in the ecology of this area of lowland tropical forest; 2) Cola lizae is endemic to Gabon and has a limited geographic distribution (Hallé 1987); and 3) Cola lizae provides a major source of food for primates, but only gorillas and occasionally chimpanzees (Pan troglodyles troglodytes Blumenbach 1779) swallow and thus disperse the large seeds. Monkeys spit out seeds and no frugivorous bats large enough to disperse the seeds occur at the Lopé. Cola lizae fruits dominate the gorillas' diet during a period of two to four months most years.

Mature Cola trees are usually of medium height $(20-25 \mathrm{~m})$ with very large, simple leaves (up to $100 \mathrm{~cm}$ by $125 \mathrm{~cm}$ ). The fruit is bright crimson when ripe, with four follicles, each a thick rubbery pod containing five to eight seeds in a clear liquid. Each large seed $(2.5 \mathrm{~cm}$ by $3.5 \mathrm{~cm})$ has two purple cotyledons encased in a fibrous coat and covered with a thin layer of succulent mesocarp, protected by a transparent yellow 'skin' (Figure 1).

The fruits of most tropical forest trees show a range of morphological characters which favour dispersal of their seeds by a particular agent (e.g. Howe \& Vande Kerckhove 1979, Janson 1983, Van der Pijl 1972). Fruit characters shown to be adapted to particular groups of animal dispersers include: colour, degree of protection, quality of the flesh, and size. The majority of fruits eaten by gorillas at Lopé fit the 'bird-monkey' dispersal syndrome (succulent or arillate/brightly coloured/unprotected) described by Gautier-Hion et al., (1985), but they also eat some 'ruminant-rodent-elephant' fruits (dry, fibrous flesh/dull coloured/large/ well protected) (Rogers et al., 1988). Cola lizae fruits show characters of both these dispersal syndromes, being brightly coloured with succulent flesh, but also large and well protected.

Here we quantify the importance of Cola lizae in the diet and examine the role of gorillas in the dispersal and propagation of this species.

\section{STUDY SITE AND METHODS}

Data come from the Lopé Reserve in central Gabon, where research on lowland gorillas and chimpanzees began in 1983. The study area of approximately $40 \mathrm{~km}^{2}$ $\left(0^{\circ} 10^{\prime} \mathrm{S}, 11^{\circ} 35^{\prime} \mathrm{E}\right)$ is mostly mature tropical forest with a zone of savannas and gallery forests in the north-east. Parts of the forest were selectively logged in the early 1960's, when a single species of tree, Aucoumea klaineana, was extracted at a rate of $1-2$ trees $\mathrm{ha}^{-1}$. 


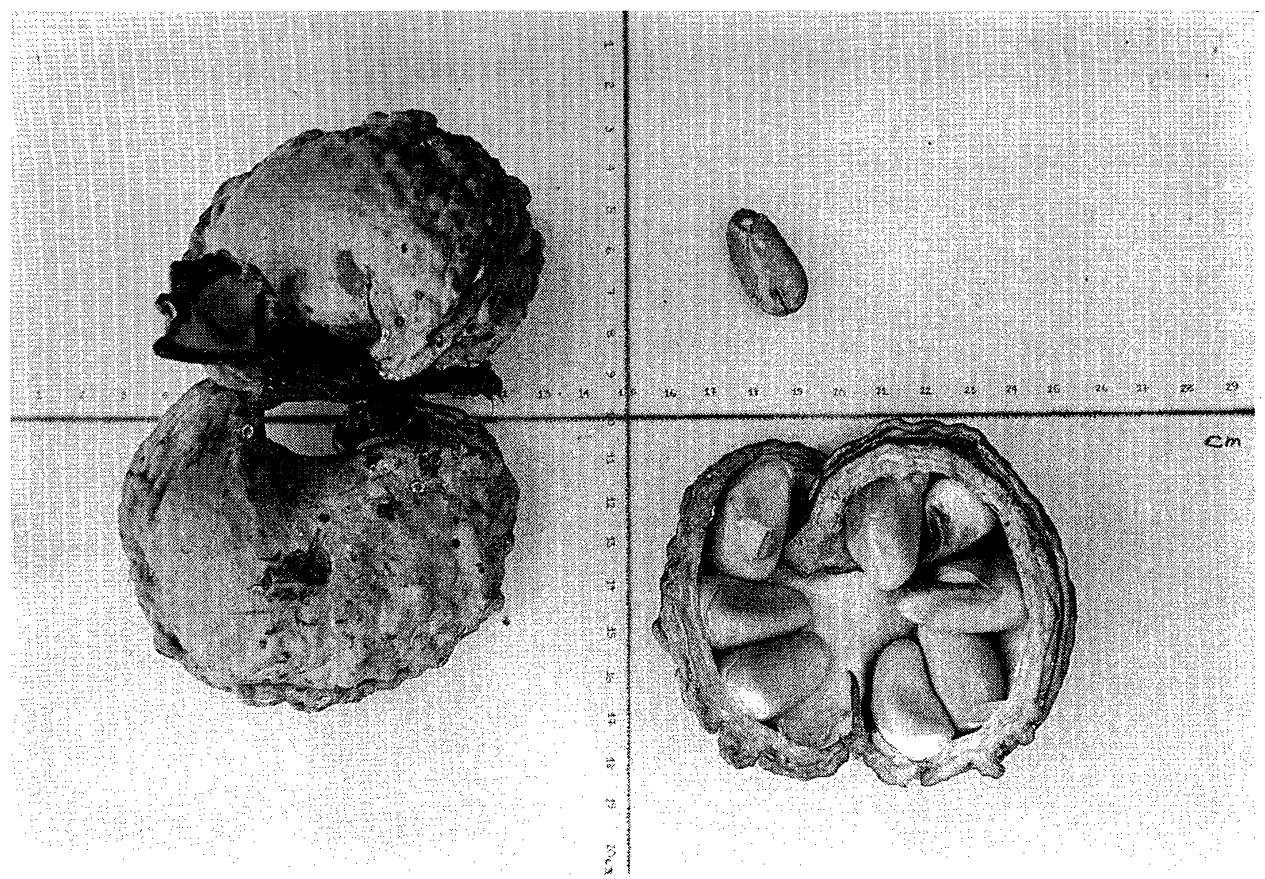

Figure 1. The fruit of Cola lizae: a pair of follicles; a cut open follicle showing the seeds with mesocarp, and a cleaned seed showing cotyledons.

Mean annual rainfall is $1532 \mathrm{~mm}$ (5-year average) with two wet seasons (March-June and October-December) and two dry seasons (January-February and July-September). Mean monthly minimum temperatures vary from $20.1-$ $23.2^{\circ}$ and mean monthly maximum temperatures from $27.0-32.8^{\circ} \mathrm{C}$.

Field procedure involved searching through the forest for gorillas, or indirect signs of their presence and activities. When gorillas were located we attempted to observe them for as long as possible. At the beginning of the study the gorillas were unused to humans and generally fled when encountered. By 1988, two groups of gorillas were partially habituated to the presence of observers but, as visibility is generally poor, observation is still difficult. Thus, we have concentrated on indirect methods to describe diet, systematically collecting fresh faeces and describing feeding traces left by gorillas (see Tutin \& Fernandez 1985 for details of field methods). Faecal samples were collected whole in the field and sealed in plastic bags. They were later weighed, and washed in sieves with $1 \mathrm{~mm}$ mesh for examination of the particulate remains. The contents of each faecal sample were listed, large seeds counted, and other items rated as being abundant, common, or few. Schaller (1963: p.90) described differences in the size and diameter of the dung of mountain gorillas related to age-class. The dung of lowland gorillas at Lopé was frequently softer and less well formed than that of mountain gorillas, but a proportion could be assigned to a particular age-class.

All trees over $10 \mathrm{~cm} \mathrm{dbh} \mathrm{(diameter} \mathrm{at} \mathrm{breast} \mathrm{height,} \mathrm{measured} 1.3 \mathrm{~m}$ from the 
ground) were identified and measured along four $10 \mathrm{~m}$ wide transects spread through the study area. The total length of transects was $4 \mathrm{~km}$, giving a 4 ha sample.

Phenological data on leaf, flower and fruit production, have been collected monthly since 1984. The 60 tree species monitored include all those whose fruits are frequently eaten by gorillas and/or chimpanzees. Ten marked individuals of each species were examined each month and the relative quantities of flowers and fruits scored from zero to a maximum of four.

Samples of gorilla foods have been collected and dried for chemical analysis (Rogers et al. 1988, 1990). Unripe and ripe Cola pods were collected from several different trees, and processed by removing the seeds and scraping off the succulent mesocarp and 'skin'. These were analysed separately, because only the mesocarp is digested. Samples were dried in an oven over paraffin lamps at not more than $50^{\circ} \mathrm{C}$. When they were of constant weight, they were sealed in plastic bags and transported to the UK for chemical analysis. Assays were done of acid-detergent fibre, crude lipid and protein, water soluble sugars, total phenols, and condensed tannins, using standard techniques. We also checked for the presence of alkaloids.

\section{RESULTS}

Gorillas at the Lopé eat 182 plant foods from 134 species and 36 families (Williamson et al. 1990). Appendix I lists 75 species, identified at least by family, of which gorillas consume succulent or fibrous pericarp/mesocarp. For 87\% (65) of these species, gorillas excrete all, or the majority of, seeds intact and presumably unharmed. The large seeds of another five species are occasionally swallowed but usually rejected after the flesh has been removed.

The phenology data on production of flowers and fruit by Cola from December 1984 to April 1989 are summarised in Figure 2. The patterns observed from 1986 to 1989 were similar, with flowers appearing in August, peaking in SeptemberOctober and fruit being most abundant in January-March. In 1985 very few fruit were present in January-March, but Cola trees produced flowers from March onwards and a minor crop of fruit in July (heavily exploited by gorillas, see below). The total fruit scores for the 10 trees monitored each month, with a theoretical maximum score of 40 are presented in Figure 2. The actual scores are low, with a maximum of 10.5 in March 1987, for two reasons: 1) the fruits of Cola tend to be hidden by the trees' enormous leaves and this probably leads to an underestimation of each tree's crop; and 2), individual Cola trees produced variable quantities of fruit and ripening was spread over several months giving a long, though obvious, fruiting season for the species. All trees in the phenology sample flowered each year but, as well as inter-annual variation in the total quantity of fruit produced, individual trees showed different fruiting patterns (see Figure 3): one tree produced fruits in each of the five years; five trees fruited in four years; one in three years; two in two years, and one tree has not yet been seen to fruit. No attempt was made to count individual fruit, but a phenology 

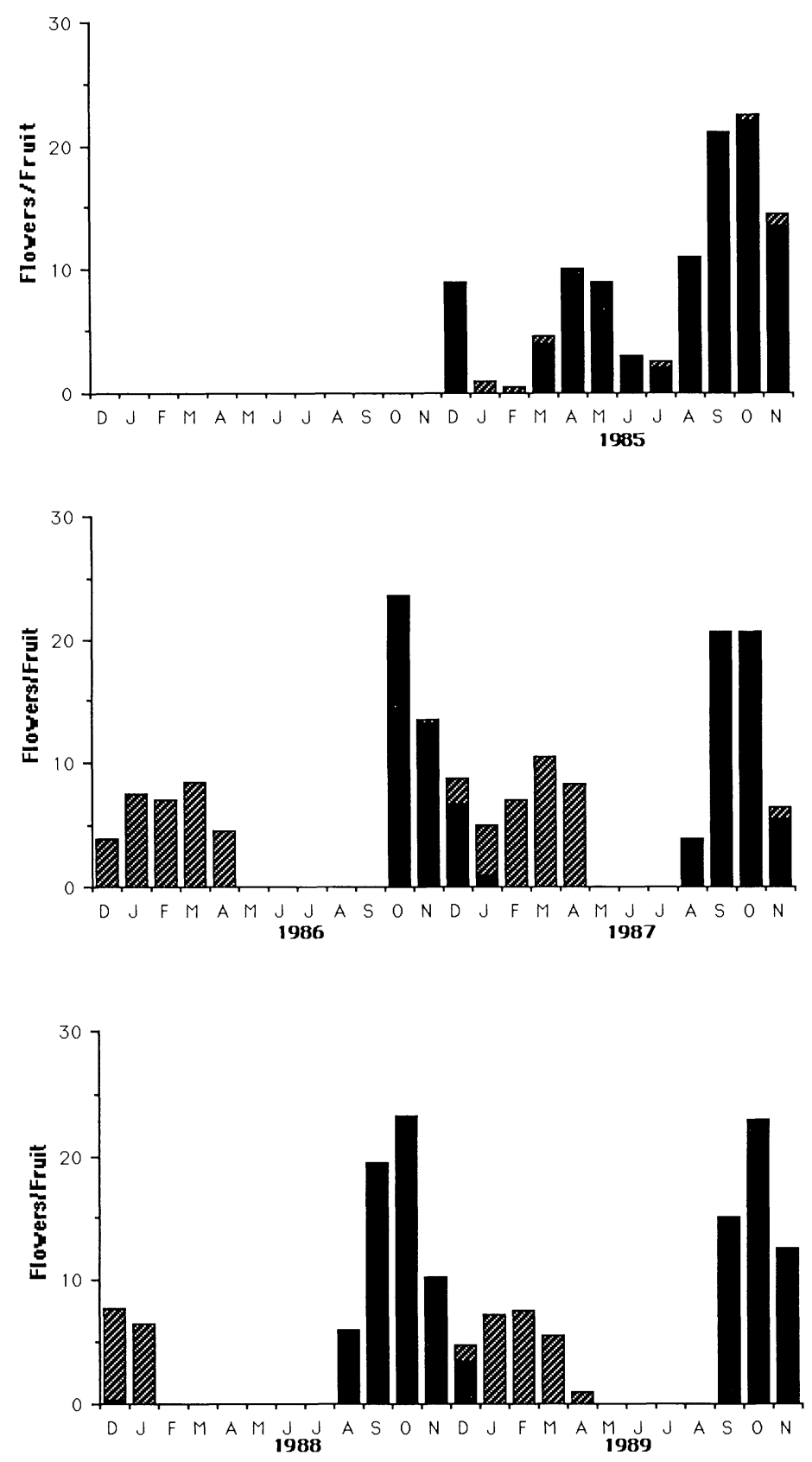

Figure 2. Production data summed for 10 Cola lizae trees over a five-year period. Flowers solid bar; fruit hatched bar. 

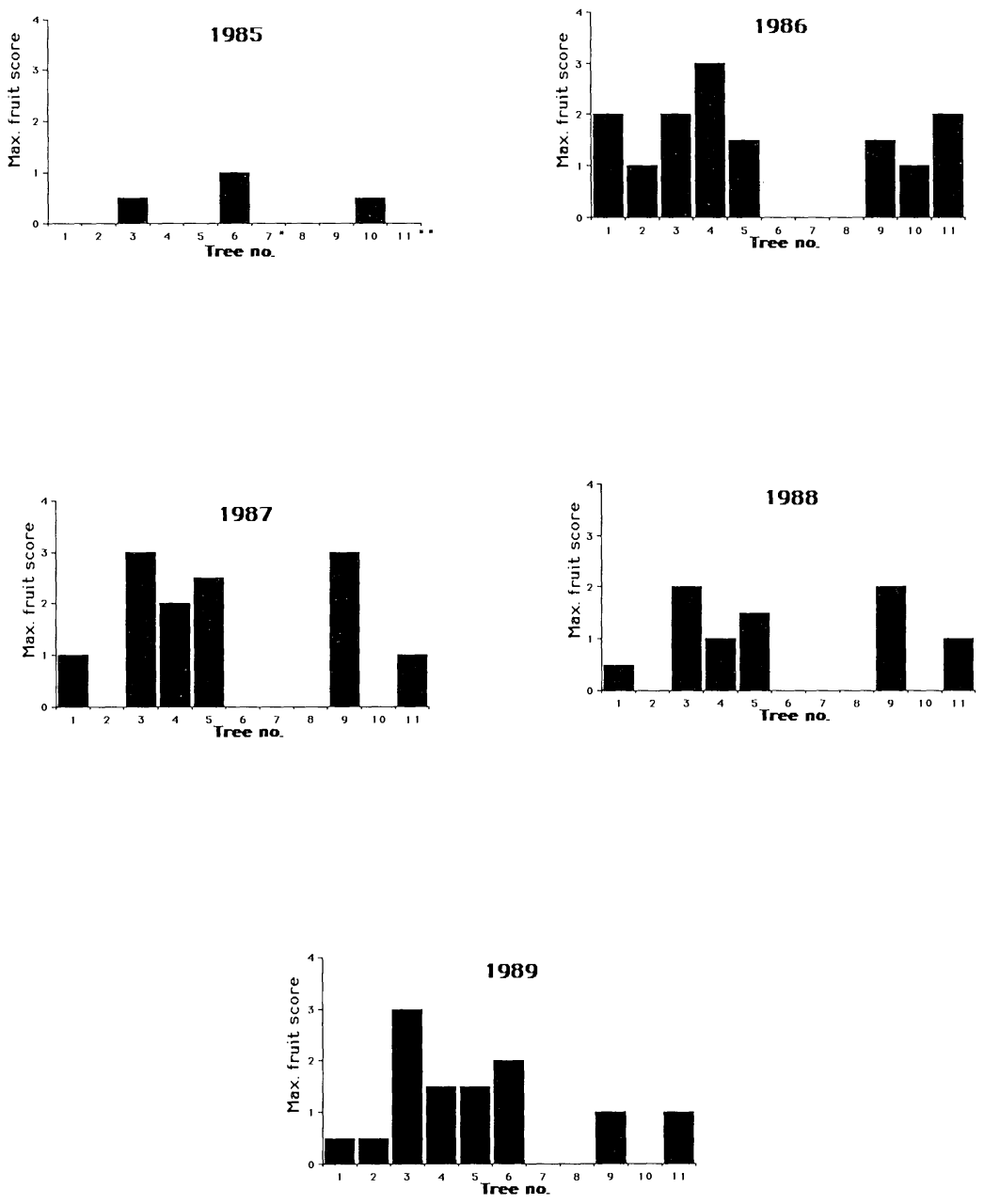

Figure 3. Annual fruit production by the 10 Cola lizae trees in the phenology sample, 1985-1989.

* Tree 7 died in November 1985. ** Tree 11 was added in November 1985 to replace tree 7.

score of one represents approximately 50 fruits (or 200 follicles).

Figures 2 and 3 do not suggest that fruit is abundant. However, Cola occurs at high frequency: 394 trees with $\mathrm{dbh} \geq 10 \mathrm{~cm}$ were recorded in 4 ha of transects (Williamson 1988). Trees of $<15 \mathrm{~cm} \mathrm{dbh}$ are not sufficiently mature to produce fruit, but nonetheless this sample included 244 Colas of $\geq 15 \mathrm{~cm} \mathrm{dbh}$, giving a mean density of 6100 mature trees $\mathrm{km}^{-2}$ in the central study area. This is a particularly high density as Cola has a patchy distribution and a 2 ha sample in an area $7 \mathrm{~km}$ west of our study area recorded a mean density of only 100 mature Cola $\mathrm{km}^{-2}$ (Harrison, pers. comm.).

Cola seeds were found in 522 of the 3123 gorilla faecal samples examined between December 1983 and April 1989. Figure 4 shows the percentage of samples containing Cola by month for this period. Cola was eaten each year and, 

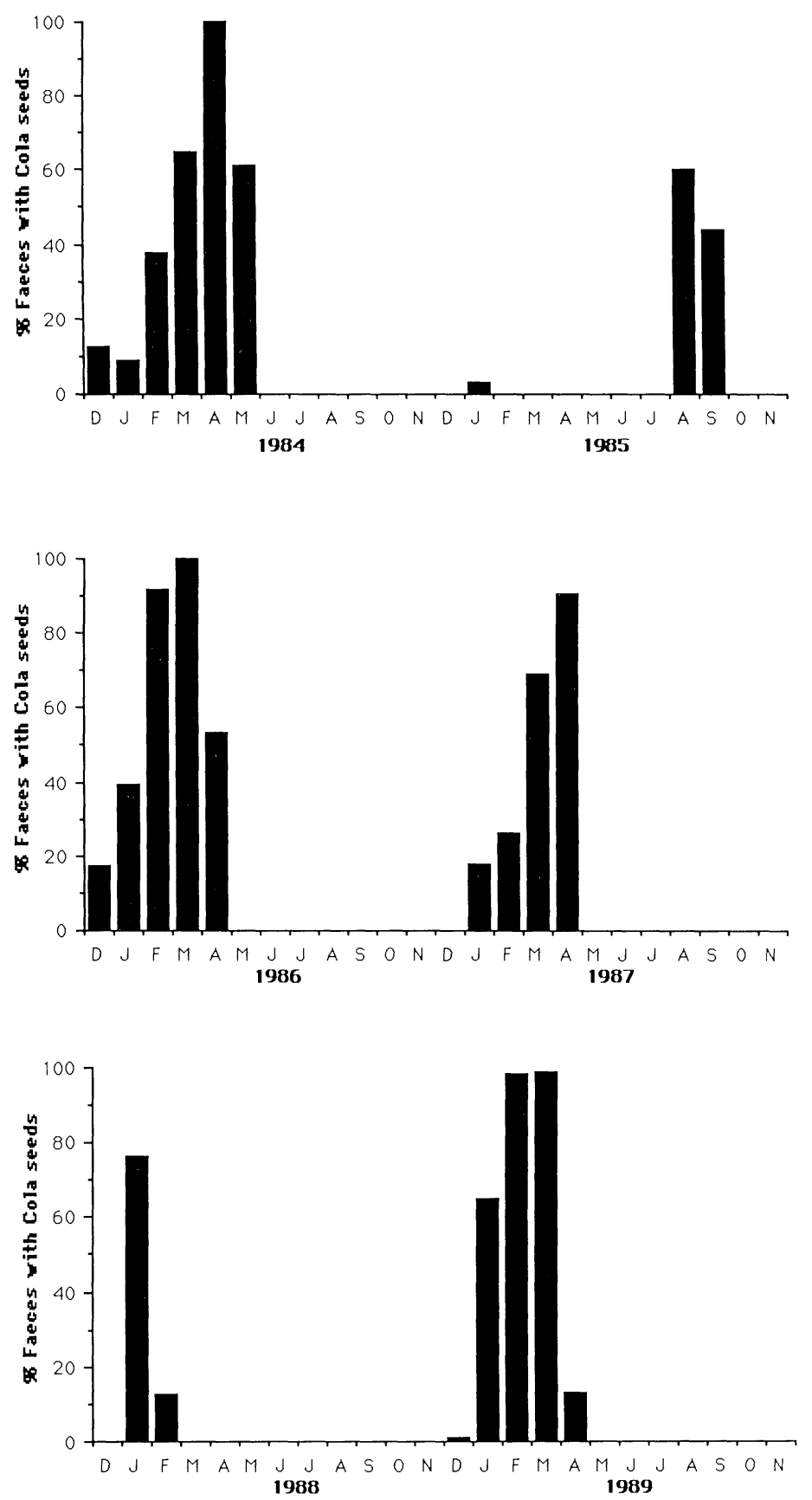

Figure 4. Percentage of gorilla faeces containing Cola lizae over a six-year period. 
except in 1985, consumption by gorillas was most frequent during the first four months of the year.

Gorillas process Cola fruits by biting into the pod, letting the clear fluid drain and then opening the pod with mouth and hands and extracting the individual seeds by mouth. The pod is then dropped and another plucked. Processing involves not only the removal of individual seeds, but also piercing of the transparent yellow 'skin' around the mesocarp: if this is not done, the mesocarp is not digested. Generally, gorillas ate fully ripe, red, fruits but some full-sized, green, fruits were eaten at the beginning of the season and in 1988, when there was an unusual scarcity of ripe fruit, most of the Cola crop was consumed in January before it was ripe (see Figure 4). Gorillas have been observed feeding for up to 11 minutes in a Cola tree and examination of feeding remains showed that a group of eight gorillas had consumed over 100 pods at one tree. Trail data from the 1989 season showed that gorillas visited up to six Cola trees in a day.

In 1989 Cola fruits were eaten from January to April. Overall, 81\% $(\mathrm{N}=234)$ of gorilla faeces collected during this four-month period contained Cola seeds. This proportion reached $98 \%(\mathrm{~N}=177)$ between 23 January and 28 March, when fruits were ripe and abundant.

Table 1 shows the mean number of seeds in each faecal sample containing Cola during the 1989 fruiting season, and that this is directly related to the rank order of body (and faecal) weight. The mean number of seeds in each sample was 30.9 for the 234 faeces collected from January-April and 38.1 for the 190 faeces that contained Cola.

Cola seeds represented a considerable proportion of the weight of faecal samples collected during the season. The total weight of the 190 samples containing Cola was $72.4 \mathrm{~kg}$, and the 7232 Cola seeds contained within them weighed $34.4 \mathrm{~kg}$. Thus, the average proportion of the faecal weight formed by Cola seeds was $47 \%$ (Range $(\mathrm{R})=1-98 \%$ ). The average wet weight of mesocarp by seed was $1.4 \mathrm{~g}$ $(\mathrm{N}=14)$, so the 'meal' represented by the average Cola-containing faecal sample was $53.3 \mathrm{~g}$ of mesocarp $(\mathrm{R}=1.4-336 \mathrm{~g})$.

The chemical analysis of Cola mesocarp, the only part of of the fruit which is

Table 1. Number of Cola seeds in gorilla faeces, JanuaryApril 1989.

\begin{tabular}{lccl}
\hline Age-class & $\begin{array}{c}\text { No. faeces } \\
\text { containing } \\
\text { Cola }\end{array}$ & $\begin{array}{c}\text { Mean No. Cola } \\
\text { seeds/faeces }\end{array}$ & Range \\
\hline Silverback & 18 & 55.3 & $1-218$ \\
Adult & 47 & 53 & $1-164$ \\
Juvenile & 38 & 23.5 & $1-87$ \\
Infant & 2 & 3.5 & $1-7$ \\
Unassigned & 85 & 33.5 & $1-240$ \\
TOTAL & 190 & 38.1 & $1-240$ \\
\hline
\end{tabular}


digested, revealed a high content of soluble carbohydrate (Table 2). As can be seen, the sugar content rises as the fruit ripens, but it is already high in full-sized unripe fruit. The levels of condensed tannins measured are not exceptionally high for gorilla foods at Lopé (Rogers 1989, Rogers et al. 1990), but might contribute to the low digestibility of the 'skin' surrounding the mesocarp, and the relative unpalatability of unripe mesocarp. No measurable alkaloids were detected in either Cola seeds or seed coats.

Defaecation rates of gorillas at Lopé are unknown at present, but it is clear from nesting sites and trails that an individual defaecates several times each day, and an estimate of 3-5 times each 24 hours is conservative. The mean number of Cola seeds in faecal samples collected during the season was 30.9, which gives 93-155 seeds excreted per gorilla each day, making a total of 11,160-18,600 seeds excreted by each gorilla during the four month Cola season. The density of gorillas in the study area is approximately one individual $\mathrm{km}^{-2}$; therefore between 11,000 and 18,000 Cola seeds are distributed $\mathrm{km}^{-2}$ of forest.

\section{Germination of Cola seeds and survival of seedlings}

Faeces collected in the field were kept, sealed in their plastic bags, for up to a week at camp before sieving. Seven faecal samples collected from a gorilla nestsite of 20-21 March 1989 were sieved two days later. We noted that 252 out of 364 Cola seeds they contained had begun to germinate and five days later, an additional 54 (kept on damp paper) had also germinated, giving $84 \%$ germination success seven days after deposition in faeces.

We also followed the fate of Cola seeds in undisturbed gorilla faeces, and made casual observations on seeds dropped below Cola trees by monkeys, and those in whole fruits which fell to the ground and rotted. We monitored germination and survival of seedlings in 34 undisturbed gorilla faecal samples at four-week intervals for six months after deposition. Sixteen of the monitored faecal samples were at a nest-site dating from 17-18 March 1989. The other 18 faeces were found in the forest between 14 March and 6 April and had been deposited by gorillas

Table 2. Chemical analysis of Cola lizae seeds and seed coats. (ND, not done because of shortage of material; NA, values not available separately because ripe seeds were dried with adhering mesocarp which was easier to scrape off without loss.)

\begin{tabular}{lrrrr}
\hline & $\begin{array}{c}\text { Unripe } \\
\text { mesocarp }\end{array}$ & $\begin{array}{c}\text { Ripe } \\
\text { mesocarp }\end{array}$ & $\begin{array}{r}\text { Ripe } \\
\text { seed }\end{array}$ & $\begin{array}{r}\text { Ripe } \\
\text { 'skin' }\end{array}$ \\
\hline \% Dry Matter & & & & \\
Crude protein & 12.3 & 3.9 & 7.7 & ND \\
Water soluble carbohydrate & 31.4 & 58.4 & 10.0 & ND \\
Crude lipid & 0.3 & 0.3 & 1.0 & ND \\
Acid-detergent fibre & 22.5 & 16.5 & 5.3 & 20.6 \\
Total phenols & 8.8 & 1.9 & 1.8 & 3.8 \\
Condensed tannins & 28.5 & 10.4 & 6.2 & 20.2 \\
\% Water & 83.0 & NA & NA & 65.9 \\
\hline
\end{tabular}


during travel and/or feeding. Cola seeds were counted at the first observation and on subsequent visits, the number and condition of surviving seedlings were noted and causes of mortality assessed when possible. Despite high germination rates, early seedling mortality was very high and, from 1043 seeds in the total sample, there were only 416 seedlings $(40 \%) 7-9$ weeks after deposition. After six months, this figure had dropped to $195(19 \%)$.

There was a striking difference between seedling survival in faeces left at nestsites compared with other areas of forest (Figure 5). Two months after deposition, 341 surviving seedlings (from 476 seeds) were present at the nest-site with a mean of $21.3(4-100)$ in each faecal sample. In the faeces from other areas of forest, only 75 surviving seedlings (from 567 seeds) remained, giving a mean of $4.2(0-$ 12). This difference is highly significant: $\chi^{2}=221, \mathrm{DF}=1, \mathrm{P}<0.001$. While seedling mortality continued to take its toll (Figure 5), six months after deposition $189(40 \%)$ seedlings still survived at the nest-site. By this time, only $6(1.1 \%)$ of those in faeces elsewhere in the forest were still viable. Figure 6 shows a group of healthy seven-week-old Cola seedlings $20-30 \mathrm{~cm}$ high) in faeces left beside a nest. Major identifiable causes of seedling mortality were: feeding on leaves by insects or ungulates, trampling by elephants, and disease.

Systematic data were not collected from Cola seeds spat out by primates or from those in fruits that fell from trees, but very few surviving seedlings were found below Cola trees seven weeks after the 1989 fruiting season.

Of 79 chimpanzee faecal samples collected during January-April 1989, five contained Cola seeds and an additional 25 had no seeds but contained the characteristic transparent skin that covers Cola mesocarp. Thus, although $38 \%$ of chimpanzee faecal samples included remnants of Cola fruit, only 6\% contained seeds, with a mean of $4.2(\mathrm{~N}=5)$ seeds in each sample $(\mathrm{R}=1-11)$.

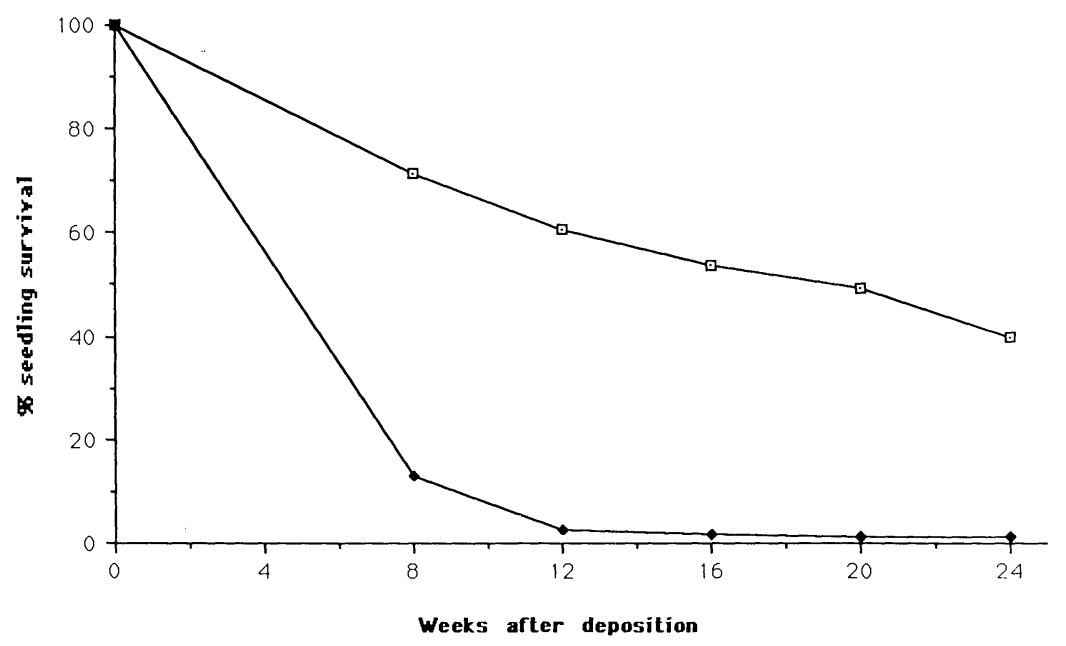

Figure 5. Survival of Cola lizae seedlings in undisturbed gorilla faeces. $\square-\square$, seedlings at nestsites; $\downarrow$, seedlings in other areas of the forest. 


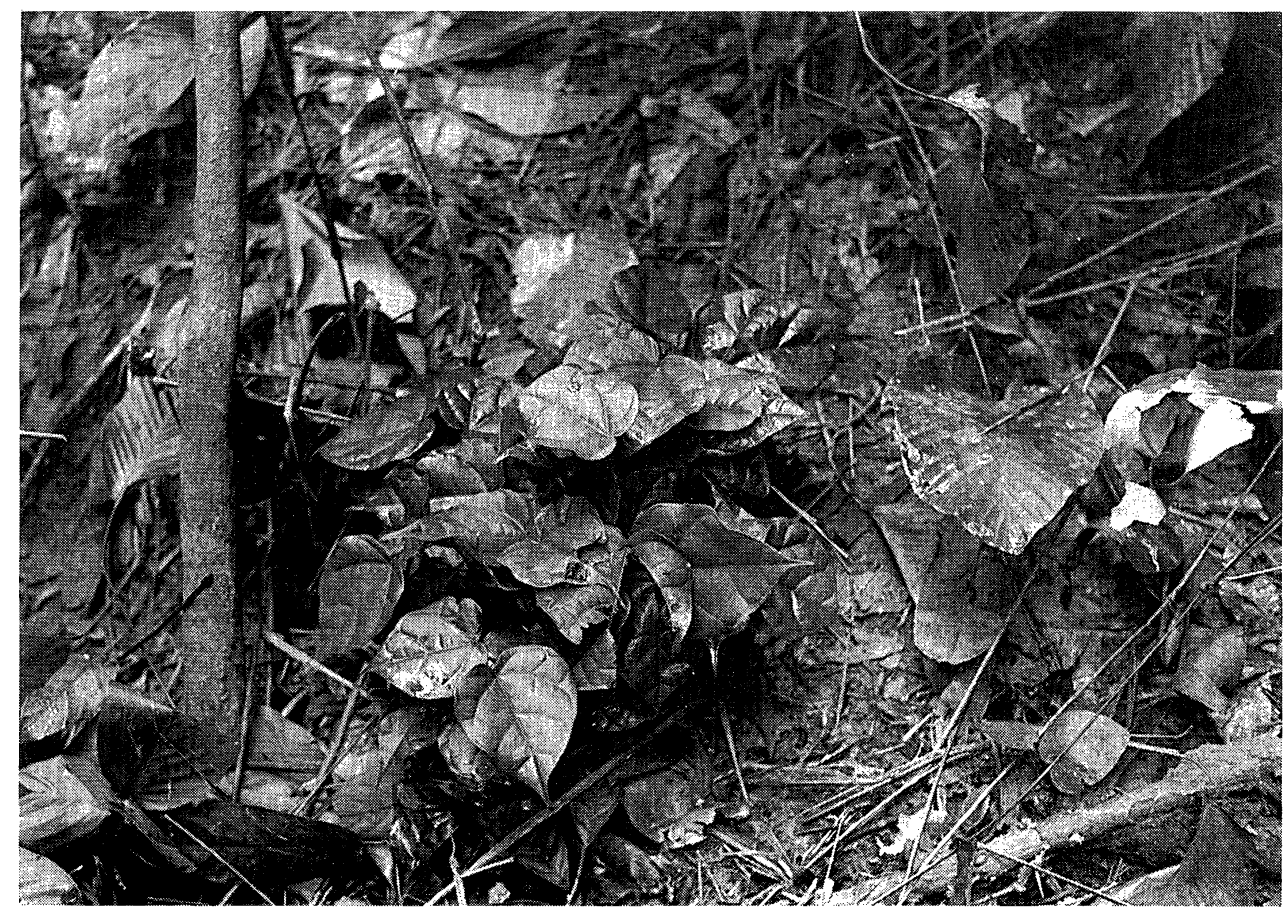

Figure 6. A group of Cola lizae seedlings in gorilla faeces left at a nest-site, seven weeks after deposition.

DISGUSSION

The fruit of Cola lizae has formed a major part of the diet of gorillas at the Lopé during the six consecutive years of this study. Despite inter-annual variation in fruit production (Figures $2 \& 3$ ), the abundance of Cola trees in the study area allowed gorillas to feed intensively on the fruit each year. The high level of Cola fruit consumption, even when phenology data indicated fruit to be relatively uncommon (see Aug-Sept 1985 data in Figures 2 \& 4), suggest that it is a highly preferred food. Cola mesocarp has one of the highest sugar levels (WSC in Table 2) of all the gorilla foods analysed from Lopé (Rogers et al. 1990) and this may explain its particular attraction.

The availability of all fruits eaten by gorillas at Lopé varies seasonally, but not all tree species have such a regular annual rhythm of production as Cola lizae. While Cola dominated the gorillas' diet for 2-4 months in each year, it was not the most commonly-eaten fruit on an annual basis, ranking seventh in 198485 (Williamson 1988) and tenth in 1988 (unpublished data). Cola lizae is one of the 15 species whose fruit is ranked as consistently important in the diet of the Lopé gorillas (see Appendix I): these are fruit which are eaten whenever they are available and the spatial distribution of which influences ranging patterns of the gorillas (Tutin et al. in prep.). So, in terms of gorilla nutrition, Cola lizae is an important but not exceptional fruit, but for Cola lizae gorillas are important 
and exceptional dispersers of seeds, depositing $11,000-18,500 \mathrm{~km}^{-2}$ in the 1989 season.

A major aspect of seed dispersal is the transport of seeds away from the parent plant. This is particularly important for a colonising species, such as Cola lizae, which thrives in light-gaps, as the probability of germination in dense shade below the large-leaved parent tree appears low (pers. obs.). There are likely to be other advantages of transport away from the parent as species-specific seed and seedling predation have been found to be greater near conspecific trees (Janzen 1970). Gorillas at Lopé travel an average of $1.2 \mathrm{~km}$ each day $(\mathrm{R}=0.3-$ $2.6 \mathrm{~km}$ ) (Tutin et al. in prep.). Gut passage time is not known for wild gorillas, although Milton (1984) found a long and variable transit time of 17-84 hours in captive gorillas. Thus, ingested seeds could be carried considerable distances before deposition.

Additional benefits of endozoochory are that seeds are surrounded by a dung matrix, which reduces desiccation and may provide an advantageous substrate for germination. Whether seeds benefit from any chemical or mechanical action of the digestive tract, or not, is debatable (Estrada \& Coates-Estrada 1986, Lieberman \& Lieberman 1986), but we can conclude that the gorilla's digestive system appears not to inhibit germination of Cola seeds as $84 \%$ of seeds from faeces had germinated seven days after deposition. Gorillas avoid chewing the unprotected cotyledons of Cola, but the fibrous coat of ripe seeds in faeces was either totally removed or loosened, presumably during passage through the gut. Assertion of positive effects of passage through a gorilla's gut on germination success cannot be made as non-ingested seeds were not monitored systematically in this study. However, Ibikunle \& Mackenzie (1974) found significantly higher germination rates in seeds of Cola nitida Schott \& Endl. which had either been soaked in water or had had the two cotyledons mechanically separated before sowing, compared with untreated seeds.

The likely advantages of gorillas as dispersal agents of Cola lizae may, to some extent, be counteracted by the large number of seeds swallowed. Gorillas ingest the seeds in vast quantities with up to 240 seeds counted in a single faecal sample. Thus, while many seeds are transported from the parent tree and germination rate is high, seedlings may be subject to intense competition within faecal clumps (cf. Howe 1980). Observations of seedling survival indicate that even six months after deposition, dominant seedlings had not clearly emerged.

Dispersal does not imply the fate of the seed (Janzen 1983), but a high-quality propagator should deposit seeds at sites favourable, or at least not adverse, to their germination. Wheelwright \& Orians (1982) state that seed dispersal lacks the precision of pollen dispersal and that, whereas 'plants can control pollinators' movements by providing nutritional and reproductive incentives at the appropriate site (flower) ..., there is no similar incentive for seed dispersers to drop seeds in appropriate places' (page 405). However, gorillas excrete up to $50 \%$ of their daily faeces at sleeping-sites (Schaller 1963:203), the rest being deposited during daily feeding and travel. Gorillas construct a new sleeping 'nest' each night and 
tend to choose open areas (where the herbaceous plants used for nest construction are common). At the Lopé, $63 \%$ of nests had no overhead cover (Williamson 1988). These conditions are likely to favour the rapid germination and growth of Cola lizae, which seems to be well adapted to colonising light gaps. The present study indicates that seedling survival is higher at nest-sites than in other parts of the forest. Observations suggest that seedlings at nest-sites are less vulnerable to trampling by elephants, or browsing by ungulates, and their good state of health and 40\% survivorship 24 weeks after deposition, suggest that typical gorilla nest-sites provide favourable micro-habitats for $C$. lizae.

It is clear that gorillas are reliable, high-quality, dispersers of Cola lizae and out data show that chimpanzees are the only other member of the diverse community of frugivores at Lopé which also disperse Cola seeds. Birds, bats and rodents have not been observed feeding on Cola fruit. The absence of mammalian seed predation suggests that the cotyledons are chemically protected. Five species of monkey eat the mesocarp, but never ingest seeds. Normally, monkeys drop seeds (unharmed) below the parent tree, but some may be transported short distances, in cheek pouches, before processing. Chimpanzees eat large amounts of Cola mesocarp but swallow relatively few seeds. The seeds' large size, 2.5$3.5 \mathrm{~cm}$ long, is obviously an important factor in their dispersal. For a small primate it is costly to fill the gut with a large non-usuable volume, so monkeys invest time and energy separating the pulp from the seeds. The different patterns of seed ingestion shown by gorillas and chimpanzees are striking given the similarity of the relationship between body and gut size (Chivers \& Hladik 1984) and gut passage time (Milton 1984) in the two species.

Elephants (Loxodonta africana cyclotis Blumenbach 1797) at the Lopé are opportunistic frugivores and show considerable dietary overlap with the apes but they do not eat Cola fruit. We can only speculate about the reasons for elephants' avoidance of this fruit. Certainly, seed size is not the explanation, as elephants are known dispersers of considerably larger seeds than C. lizae, e.g. Panda oleosa Pierre, Saccoglottis gabonensis (Baill.) Urb, Klainedoxa gabonensis Baill., and Pentadesma butyracea Sabine (pers. obs.; Alexandre 1978; Lieberman et al. 1987). Elephants are skilful manipulators and able to extract large pulp-covered seeds from fruits such as Mammea africana Sabine (pers. obs.). The cotyledons of C. lizae are not physically protected either by a rigid fruit shell, or by a lignified seed coat, but they may be chemically defended: the clear fluid found in the fruits of certain Cola species contains a substance that inhibits growth of other seedlings (Miège et al., 1970) and which may have an adverse effect on the metabolism of mammals. The unusual form of Cola fruits may render them difficult for elephants to manipulate without ingesting the fluid. This hypothesis gains support from our observation that primates empty this fluid from the pods of Cola before they eat the mesocarp. It is also possible that the crimson cotyledons of C. lizae contain caffein, as do the seeds of the commercially exploited Cola nitida (Ogutuga 1975). If so, elephants may not eat the fruit, because they are unable to avoid biting into the cotyledons during feeding. 
Gorillas at Lopé disperse seeds of at least 65 species of plants and their impact on the ecology of the forest must be considerable. The fruit eaten by gorillas at Lopé are diverse both in morphological characters and chemistry (Rogers et al. 1990). It seems that gorillas bridge the broad vertebrate disperser categories, having a combination of morphological characters that set them slightly apart (large gut, climbing ability, strong jaws). Patterns of ranging and other behaviours (e.g. choice of nesting sites) also make them seed dispersers 'par excellence', at least for light-tolerant plant species.

In the absence of historical data, co-evolution between gorillas and Cola lizae can only be suggested but such specialization to a single species of disperser is unusual (Herrera 1986, Wheelwright \& Orians 1982). As C. lizae is the commonest tree in the study area, it appears to be a system that works well. However, the important local differences in the density of $C$. lizae and its restricted geographical range, require explanation. Gorillas still occur in the majority of Gabon's forests (Tutin \& Fernandez 1984), but C. lizae is restricted to a small area in the centre of the country (Hallé 1987).

The discovery that the commonest tree in our study area at Lopé was an undescribed species was surprising and provides yet another example of the incompleteness of the understanding of tropical forest ecosystems. The specialised disperser relationship between $C$. lizae and gorillas is an example of the delicate links that can exist within an ecosystem. Alexandre (1978) found indications that local extermination of elephants (by hunting) in some areas of forest in Ivory Coast led to the absence of young trees of species with elephant-dispersed seeds. If gorillas in central Gabon had been as heavily persecuted as those in some areas, perhaps Cola lizae would not have survived long enough to have been identified and described.

\section{SUMMARY}

1. Gorillas in the Lopé Reserve, central Gabon, are the most frugivorous population of this species studied to date (Williamson et al. 1990) and they disperse seeds of at least 65 plant species. The fruits eaten by gorillas are morphologically and chemically diverse (Rogers et al. 1990). Lowland gorillas are likely to exert a strong influence on the ecology of tropical forests in which they occur.

2. As part of an on-going study of the behavioural ecology of lowland gorillas at the Lopé, faeces are collected and analysed to describe the gorillas' diet, and phenology data collected monthly on leaf, flower and fruit production of 60 species of trees whose fruits are regularly consumed by gorillas.

3. Analysis of these data over a six-year period revealed that gorillas eat large quantities of Cola lizae fruits whenever they are available. C. lizae is an endemic species with a limited geographical distribution (Hallé 1987), but is the commonest tree in the Lopé study area. The fruits are eaten by other primates, but the large seeds are very rarely swallowed except by gorillas. 
Gorillas deposited between 11,000 and 18,000 Cola seeds $\mathrm{km}^{-2}$ in the fourmonth season in 1989 .

4. Given this specific disperser relationship, we examined the fate of a sample of 1043 Cola seeds in undisturbed gorilla faeces. The germination rate was high, but seedling mortality in the first eight weeks after deposition was also high. There was a very significant difference between seedling survival rate in faeces deposited at nest-sites, and those in other areas of the forest. Seedlings thrived at nest-sites which are typically in areas of forest where overhead cover is sparse, such as light gaps, and six months after deposition $40 \%$ of nest-site seedlings were surviving, compared with only $1 \%$ in other areas.

5. Chemical analysis of $C$. lizae fruits revealed that the mesocarp (the only part digested by gorillas) has a high sugar content. Data from a related species, C. nitida, suggest that the fruit may be chemically protected from some potential consumers by the composition of the clear fluid surrounding the seeds and by concentrations of caffein in the cotyledon (Miège et al. 1970, Ogutuga, 1975).

6. Cola lizae is exceptional because gorillas appear to be the sole dispersers of its large seeds. Such a specific plant-animal relationship is unusual (Herrera 1986, Wheelwright \& Orians, 1982) but appears successful as mature Cola trees occur at a mean density of $6100 \mathrm{~km}^{-2}$ in the study area.

\section{ACKNOWLEDGEMENTS}

We thank the L.S.B. Leakey Foundation, the World Wide Fund for Nature, the National Geographic Society, the Wenner-Gren Foundation and especially the Centre International de Recherches Médicales de Franceville for supporting this research; also Alphonse Mackanga and the Direction de la Faune for permission to work in the Lopé. We are very grateful to the following colleagues who contributed to data collection at the Lopé: Catherine Bouchain, Jean-Yves Collet, Alick Cruickshank, Anna Feistner, Stephanie Hall, Fiona Maisels, Ann Pierce, Ben Voysey, Lee White and Dorothea Wrogemann. We also thank Chris Wilks, Lee White, Diana Lieberman and an anonymous referee for constructive comments on the manuscript.

\section{LITERATURE CITED}

ALEXANDRE, D. Y. 1978. Le role disseminateur des elephants en forêt de Tai, Cote-d'Ivoire. La Terre et la Vie $32: 47-72$.

CHIVERS, D. J. \& HLADIK, C. M. 1984. Diet and gut morphology in primates. Pp 213-230 in Chivers, D. J., Wood, B. A. \& Bilsborough, A. (eds). Food acquisition and processing in primates. Plenum Press, New York. 576 pp. 
ESTRADA, A. \& COATES-ESTRADA, R. 1984. Fruit eating and seed dispersal by howling monkey (Alouatta palliata) in the tropical rain forest of Los Tuxtlas, Mexico. American Journal of Primatology 6:77-91.

ESTRADA, A. \& COATES-ESTRADA, R. 1986. Frugivory in howling monkeys (Alouatta palliata) at Los Tuxtlas, Mexico: dispersal and fate of seeds. Pp. 94-104 in Estrada, A. \& Fleming, T. H. (eds). Frugivores and seed dispersal. Dr. W. Junk Publishers, Dortrecht. 392 pp.

GALDIKAS, B. M. F. 1982. Orang-utan as seed-dispersers at Tanjung Puting, central kalimantan: implications for conservation. Pp. 285-298 in Boer, L. E. M. de (ed.). The orang utan, its biology and conservation. Boston Hingham, The Hague. 353 pp.

GARBER, P. A. 1986. The ecology of seed dispersal in two species of Callitrichid primates (Saguinus mystax and Saguinus fuscicollis). American Journal of Primatology 10:155-170.

GAUTIER-HION, A. 1984. La dissemination des graines par les cercopithecides forestier Africans. Revue d'Ecologie (Terre et Vie) 39:159-165.

GAUTIER-HION, A., DUPLANTIER, J-M., QURIS, R., FEER, F., SOURD, C., DECOUX, J-P., DUBOST, G., EMMONS, L., ERARD, C., HECKETSWEILER, P., MOUNGAZI, A., ROUSSILHON, G. \& THIOLLAY, J-M. 1985. Fruit characters as a basis of fruit choice and seed dispersal in a tropical forest vertebrate community. Oecologia 65:324-337.

HALLE, N. 1987. Cola lizae N. Hallé (Sterculiaecea) Nouvelle espece du Moyen Ogooue (Gabon). Adansonia 3:229-237.

HERRERA, G. M. 1986. Vertebrate-dispersed plants: why they don't behave the way they should. Pp. 5-18 in Estrada, A. \& Fleming, T. H. (eds). Frugivores and seed dispersal. Dr W. Junk Publishers, Dordrecht. 392 pp.

HLADIK, C. M. \& HLADIK, A. 1967. Observations sur le role des primates dans la dissémination des vegetaux de la forêt gabonaise. Biologia Gabonica 3:43-58.

HOWE, H. F. 1980. Monkey dispersal and waste of a neotropical fruit. Ecology 61:944-959.

HOWE, H. F. \& VANDE KERGKHOVE, G. A. 1979. Fecundity and seed dispersal of a tropical tree. Ecology 60:180-189.

IBIKUNLE, B. O. \& MACKENZIE, J. A. 1974. Germination of kola (Cola mitida (Vent) Schott Endl). Turrialba 24:187-192.

IDANI, G. 1986. Seed dispersal by pygmy chimpanzees (Pan paniscus): a preliminary report. Primates 27: 411-447.

JANSON, G. H. 1983. Adaptation of fruit morphology to dispersal agents in a neotropical forest. Science 219:187-189.

JANZEN, D. H. 1970. Herbivores and the number of tree species in tropical forests. American Naturalist 104: 501-528.

JANZEN, D. H. 1983. Seed and pollen dispersal by animals: convergence in the ecology of contamination and sloppy harvest. Biological foumal of the Linnean Society 20:103-113.

LIEBERMAN, D., HALL, J. B., SWAINE, M. D. \& LIEBERMAN, M. 1979. Seed dispersal by baboons in the Shai Hills, Ghana. Ecology 60:65-75.

LIEBERMAN, M. \& LIEBERMAN, D. 1986. An experimental study of seed ingestion and germination in a plant-animal assemblage in Ghana. Journal of Tropical Ecology 2:113-126.

LIEBERMAN, D., LIEBERMAN, M. \& MARTIN, C. 1987. Notes on seeds in elephant dung from Bia National Park, Ghana. Biotropica 19:365-369.

MIEGE, J., MIEGE, M. N. \& RIC:HTI, A. 1970. Etude biologique et biochimique du liquide contenu dans les fruits de deux espèces de Cola. Archives des Sciences 23:151-195.

MILTON, K. 1984. The role of food-processing factors in primate food choice. Pp. 249-279 in Rodman, P. S. \& Cant, J. G. H. (eds). Adaptations for foraging in nonhuman primates. Columbia University Press, New York. 351 pp.

OGUTUGA, D. B. A. 1975. Chemical composition and potential commercial uses of kola nut, Cola nitida, Vent. (Schott \& Endlicher) Ghana Journal Agricultural Science 8:121-125.

ROGERS, M. E. 1989. The feeding ecology of lowland gorillas in Gabon. Anthroquest 39:12-14.

ROGERS, M. E., WILliamSON, E. A., TUTIN, C. E. G. \& FERNANDEZ, M. 1988. Effects of the dry season on gorilla diet in Gabon. Primate Report 22: 25-33.

ROGERS, M. E., MAISELS, F., WILLIAMSON, E. A., FERNANDEZ, M. \& TUTIN, C. E. G. 1990. The diet of gorillas in the Lopé Reserve, Gabon: a nutritional analysis. Oecologia 84:326-339.

SGHALLER, G. B. 1963. The mountain gorilla: ecology and behavior. University of Chicago Press, Chicago. 431 pp.

TAKASAKI, H. 1983. Seed dispersal by chimpanzees: a preliminary note. African Study Monographs 3: 105-108.

TUTIN, C. E. G. \& FERNANDEZ, M. 1984. Nationwide census of gorilla (Gorilla gorilla gorilla) and chimpanzee (Pan troglodytes troglodytes) populations in Gabon. American foumal of Primatology 6:313-336.

TUTIN, G. E. G. \& FERNANDEZ, M. 1985. Foods consumed by sympatric populations of Gorilla gorilla gorilla and Pan troglodytes troglodytes in Gabon: some preliminary data. International Joumal of Primatology 6: $27-43$. 
TUTIN, C. E. G. \& FERNANDEZ, M. 1987. Sympatric gorillas and chimpanzees in Gabon. Anthroquest $37: 3-6$.

TUTIN, G. E. G., FERnANDEZ, M., ROGERS, M. E. R. \& WILliAMSON, E. A. In preparation. A preliminary analysis of the social structure of lowland gorillas in the Lopé Reserve, Gabon. For the Proceedings of the XIIth Congress of the International Primatological Society.

VAN DER PIJL, L. 1972. Principles of dispersal in higher plants. (2nd edition) Springer Verlag, Berlin, $162 \mathrm{pp}$.

WHEELWRIGHT, N. \& ORIANS, G. 1982. Seed dispersal by animals: contrasts with pollen dispersal, problems of terminology, and constraints on coevolution. American Naturalist 119:402-413.

WILLIAMSON, E. A. 1988. Behavioural ecology of western lowland gorillas in Gabon. PhD thesis, University of Stirling, Scotland. 169 pp.

WILliamSON, E. A., TUTIN, C. E. G., ROGERS, M. E. \& FERNANDEZ, M. 1990. Composition of the diet of lowland gorillas at Lopé in Gabon. American Fournal of Primatology 21:265-277.

Accepted 24 July 1990

Appendix 1. Characteristics of fruit consumed by lowland gorillas at the Lopé, fate of seeds and importance in the diet

\begin{tabular}{|c|c|c|c|c|c|c|}
\hline \multirow[b]{2}{*}{ Scientific Name or Number } & \multirow[b]{2}{*}{ Family } & \multicolumn{3}{|c|}{ Fruit characteristics } & \multirow[b]{2}{*}{$\begin{array}{l}\text { Fate of } \\
\text { seeds }\end{array}$} & \multirow[b]{2}{*}{$\begin{array}{l}\text { Import } \\
\text { in diet }\end{array}$} \\
\hline & & Size & Colour & $\begin{array}{l}\text { Seed } \\
\text { size }\end{array}$ & & \\
\hline Aframomum longipetiolatum Koech. & ZINGIBERAGEAE & $\mathrm{L}$ & RED & S & 1 & 3 \\
\hline Aframomum sp. nov. & ZINGIBERAGEAE & $\mathrm{L}$ & RED & $\mathrm{S}$ & 1 & 1 \\
\hline Aframomum ?leptolepis Shum. & ZINGIBERAGEAE & $\mathrm{L}$ & RED & $\mathrm{S}$ & 1 & 3 \\
\hline Antidesma vogeliamum Müll. Arg. & EUPHORBIACEAE & $\mathrm{S}$ & PURPLE & S & 1 & 2 \\
\hline Antidesma sp \#251 & EUPHORBIACEAE & $\mathrm{S}$ & PURPLE & $\mathrm{S}$ & 1 & 3 \\
\hline Antrocaryon klaineanum Pierre & ANNONACEAE & M & YELLOW & $\mathrm{L}$ & 1 & 3 \\
\hline Celtis lessmannii Rendle & ULMACEAE & M & GREEN & M & 1 & 1 \\
\hline Chrysophyllum subnudum Baker & SAPOTACEAE & $\mathrm{L}$ & GREEN & $\mathrm{L}$ & 1 & 3 \\
\hline Cissus dinklagei Gilg \& Brandt & VITACEAE & M & ORANGE & M & 1 & 2 \\
\hline Cola lizae N. Hallé & STERCULIACEAE & $\mathrm{L}$ & RED & $\mathrm{L}$ & 1 & 1 \\
\hline $\begin{array}{l}\text { Dacryodes normandii } \\
\text { Aubr. \& Pellegr. }\end{array}$ & BURSERACEAE & M & PURPLE & $\mathrm{L}$ & 1 & 1 \\
\hline Detarium macrocarpum Harms. & CAESALP. & $\mathrm{L}$ & GREEN & VL & 3 & 4 \\
\hline Dialium ?soyauxii Harms. & CAESALP. & M & BROWN & M & 2 & 1 \\
\hline Dialium sp \#118 & GAESALP. & M & BROWN & M & 1 & 3 \\
\hline $\begin{array}{l}\text { Diospyros abyssinica } \\
\text { (Hiern) F. White }\end{array}$ & EBENACEAE & $\mathrm{S}$ & RED & $\mathrm{S}$ & 1 & 3 \\
\hline Diospyros dendo Welw. ex Hiern & EBENACEAE & M & RED & M & 2 & 1 \\
\hline $\begin{array}{l}\text { Diospyros cf. iturensis } \\
\text { (Gürke) R. Let. \& F. White }\end{array}$ & EBENACEAE & M & YELLOW & M & 1 & 4 \\
\hline Diospyros polystemon Gürke & EBENACEAE & M & RED & M & 2 & 1 \\
\hline Diospyros suaveolens Gürke & EBENACEAE & $\mathrm{L}$ & BROWN & $\mathrm{L}$ & 1 & 5 \\
\hline Drypetes sp \#264 & EUPHORBIACEAE & M & GREEN & M & 1 & 4 \\
\hline Duboscia macrocarpa Bocq. & TILIACEAE & $\mathrm{L}$ & BROWN & $\mathrm{S}$ & 1 & 5 \\
\hline Enantia chlorantha Oliv. & ANNONACEAE & M & RED & M & 1 & 2 \\
\hline $\begin{array}{l}\text { Ficus macrosperma } \\
\text { Mildbr. \& Hutch. }\end{array}$ & MORACEAE & $\mathrm{L}$ & GREEN & $\mathrm{S}$ & 1 & 5 \\
\hline Ficus mucuso Ficalho & MORACEAE & M & GREEN & $\mathrm{S}$ & 1 & 5 \\
\hline Ficus polita Vahl & MORACEAE & M & GREEN & $\mathrm{S}$ & 1 & 5 \\
\hline Ficus recurvata De Wild & MORACEAE & $\mathrm{M}$ & GREEN & $\mathrm{S}$ & 1 & 5 \\
\hline Ficus thonningii $\mathrm{Bl}$. & MORAGEAE & $\mathrm{S}$ & GREEN & $\mathrm{S}$ & 1 & 5 \\
\hline Gambeya africana Pierre & SAPOTACEAE & $\mathrm{L}$ & ORANGE & $\mathrm{L}$ & 1 & 1 \\
\hline Grewia sp \#343 & ANACARDIACEAE & M & RED & M & 1 & 3 \\
\hline Heisteria parvifolia Engl. \& Diels & OLACACEAE & M & WHITE & M & 1 & 2 \\
\hline Hexalobus crispiftorus A. Rich. & ANNONACEAE & $\mathrm{L}$ & ORANGE & M & 1 & 2 \\
\hline Irvingia gabonensis Baill. & IRVINGIACEAE & $\mathrm{L}$ & GREEN & VL & $4 / 1$ & 1 \\
\hline
\end{tabular}




\begin{tabular}{|c|c|c|c|c|c|c|}
\hline \multirow[b]{2}{*}{ Scientific Name or Number } & \multirow[b]{2}{*}{ Family } & \multicolumn{3}{|c|}{ Fruit characteristics } & \multirow[b]{2}{*}{$\begin{array}{l}\text { Fate of } \\
\text { seeds }\end{array}$} & \multirow[b]{2}{*}{$\begin{array}{l}\text { Import } \\
\text { in diet }\end{array}$} \\
\hline & & Size & Colour & $\begin{array}{l}\text { Seed } \\
\text { size }\end{array}$ & & \\
\hline Irvingia grandifolia Hallier & IRVINGRACEAE & $\mathrm{L}$ & GREEN & VL & $4 / 1$ & 4 \\
\hline Klainedoxa gabonensis Baill. & IRVINGIACEAE & $\mathrm{L}$ & GREEN & VL & $4 / 1$ & 2 \\
\hline Klainedoxa sp \#208 & IRVINGIACEAE & $\mathrm{L}$ & GREEN & VL & $4 / 1$ & 3 \\
\hline $\begin{array}{l}\text { Lecaniodiscus cupanoides } \\
\text { Planch. ex Benth }\end{array}$ & SAPINDACEAE & M & BROWN & M & 1 & 1 \\
\hline Mammea africana Sabine & GUTTIFERAE & $\mathrm{L}$ & BROWN & VL & 4 & 3 \\
\hline Mangifera indica Linn. & ANNONACEAE & $\mathrm{L}$ & GREEN & VL & $4 / 1$ & 3 \\
\hline Megaphrynium gabonense Koech. & MARANTACEAE & $\mathrm{M}$ & RED & $\mathrm{M}$ & 1 & 4 \\
\hline $\begin{array}{l}\text { Megaphrynium macrostachyum } \\
\text { (Benth.) M.-Redh. }\end{array}$ & MARANTACEAE & M & ORANGE & M & 1 & 4 \\
\hline Monanthotaxis congensis Baill. & ANNONACEAE & $\mathrm{M}$ & RED & M & 1 & 4 \\
\hline Monodora angolensis Dunal & ANNONACEAE & $\mathrm{L}$ & GREEN & M & 1 & 3 \\
\hline Myrianthus arboreus P. Beauv. & MORACEAE & VL & YELLOW & M & 1 & 4 \\
\hline $\begin{array}{l}\text { Nauclea didderichi } \\
\text { (De Wild.) Merrill }\end{array}$ & RUBIACEAE & $\mathrm{L}$ & BROWN & $\mathrm{S}$ & 1 & 2 \\
\hline $\begin{array}{l}\text { Nauclea vandeguchtii } \\
\text { (De Wild.) Petit }\end{array}$ & RUBIACEAE & L & GREEN & $\mathrm{S}$ & 1 & 3 \\
\hline Parkia bicolor A. Chev. & MIMOSACEAE & VL & PURPLE & M & 1 & 2 \\
\hline Parkia filicoidea Welw. ex Oliv. & MIMOSACEAE & VL & GREEN & $\mathrm{M}$ & 1 & 2 \\
\hline Pentadesma butyracea Sabine & GUTTIFERAE & $\mathrm{VL}$ & BROWN & VL & $4 / 3$ & 1 \\
\hline $\begin{array}{l}\text { Plagiostyles africana } \\
\text { (Müll. Arg) Prain }\end{array}$ & EUPHORBIACEAE & M & RED & M & 1 & 3 \\
\hline $\begin{array}{l}\text { Porterandia cladantha } \\
\text { (K. Shum.) Keay }\end{array}$ & RUBIACEAE & M & ORANGE & $\mathrm{S}$ & 1 & 2 \\
\hline Pseudospondias longifolia Engl. & ANACARDIACEAE & M & RED & M & 1 & 3 \\
\hline Pseudospondias microcarpa Engl. & ANACARDIACEAE & M & PURPLE & $\mathrm{M}$ & 1 & 5 \\
\hline Psidium sp \#53 & MYRTACEAE & M & YELLOW & $\mathrm{S}$ & 1 & 1 \\
\hline $\begin{array}{l}\text { Psychotria peduncularis } \\
\text { (Salisb.) Steyerm. }\end{array}$ & RUBIACEAE & $\mathrm{S}$ & BLUE & $\mathrm{S}$ & 1 & 3 \\
\hline Psychotria vogeliana Benth. & RUBIACEAE & $\mathrm{S}$ & WHITE & $\mathrm{S}$ & 1 & 2 \\
\hline Rutidea dupuisii De Wild. & RUBIACEAE & $\mathrm{M}$ & ORANGE & $\mathrm{S}$ & 1 & 4 \\
\hline Saccoglottis gabonensis (Baill.) Urb. & HUMIRIACEAE & $\mathrm{L}$ & GREEN & $\mathrm{L}$ & 4 & 3 \\
\hline Santiria trimera (Oliv.) Aubr. & BURSERACEAE & M & PURPLE & M & 1 & 1 \\
\hline $\begin{array}{l}\text { Scytopetalum ?klaineanum } \\
\text { Pierre ex Engl. }\end{array}$ & SCYTOPETALAC. & M & PURPLE & $\mathrm{M}$ & 1 & 3 \\
\hline Treculia africana Decne. & MORACEAE & VL & GREEN & M & $3 / 1$ & 3 \\
\hline Trichoscypha acuminata Engl. & ANACARDIACEAE & $\mathrm{L}$ & RED & $\mathrm{L}$ & 1 & 2 \\
\hline $\begin{array}{l}\text { Uapaca ?acuminata } \\
\text { (Hutch.) Pax ex K. Hoffm. }\end{array}$ & EUPHORBIACEAE & M & GREEN & M & 2 & 3 \\
\hline Uapaca guineensis Müll. Arg. & EUPHORBIACEAE & M & GREEN & M & 2 & 1 \\
\hline Uapaca of sansibarica Pax. & EUPHORBIACEAE & M & GREEN & M & 2 & 3 \\
\hline Uapaca sp \#299 & EUPHORBIACEAE & M & GREEN & M & 2 & 3 \\
\hline Uvaria sp \#256 & ANNONACEAE & M & ORANGE & M & 1 & 3 \\
\hline Vitex doniana Sweet & VERBENAGEAE & M & BLACK & M & 1 & 5 \\
\hline Zanha golungensis Hiern & SAPINDACEAE & M & ORANGE & M & 1 & 1 \\
\hline SEGC \#36 & APOCYNACEAE & $\mathrm{L}$ & ORANGE & $\mathrm{L}$ & 1 & 3 \\
\hline SEGG \#46 & APOCYNACEAE & VL & ORANGE & $\mathrm{L}$ & 1 & 3 \\
\hline SEGG \#58 & APOCYNACEAE & $\mathrm{L}$ & ORANGE & $\mathrm{L}$ & 1 & 3 \\
\hline SEGC \#56 & CELASTRACEAE & $\mathrm{L}$ & RED & $\mathrm{S}$ & 1 & 4 \\
\hline SEGC \#288 & RUBIACEAE & $\mathrm{M}$ & WHITE & $\mathrm{S}$ & 1 & 3 \\
\hline SEGC \#291 & RUBIACEAE & M & ORANGE & $\mathrm{S}$ & 1 & 3 \\
\hline SEGC \#318 & SAPOTACEAE & $\mathrm{M}$ & GREEN & $\mathrm{M}$ & 1 & 3 \\
\hline
\end{tabular}

KEY:

Fruit Size, classed by largest diameter of whole fruit:

$\mathrm{S}=$ Small, $<5 \mathrm{~mm}$

$\mathrm{M}=$ Medium, $10-30 \mathrm{~mm}$

$\mathrm{L}=$ Large, $30-100 \mathrm{~mm}$ 
$\mathrm{VL}=$ Very Large, $>100 \mathrm{~mm}$

Seed Sizé, classed by largest diameter:

$\mathrm{S}=$ Small, $<5 \mathrm{~mm}$

$\mathrm{M}=$ Medium, 5-15 $\mathrm{mm}$

$\mathrm{L}=$ Large, $15-40 \mathrm{~mm}$

$\mathrm{VL}=$ Very Large, $>40 \mathrm{~mm}$

Fate of Seeds:

1: Passed intact in faeces

2: Majority of seeds passed intact, minority destroyed by chewing

3: All seeds destroyed in feeding

4: Seeds not swallowed

N.B. If two categories listed, first is the usual pattern for ripe fruit.

Importance in the diet:

1: Eaten whenever available;

2: Frequency/quantity of consumption less than would be expected from availability;

3: Uncommon species, thus availability always limited;

4: Consumed infrequently and/or in small amounts;

5: Large differences in patterns of consumption either between years or between groups.

\section{BOOK ANNOUNGEMENT}

\section{Index Herbariorum, Edition 8}

HOLMGREN, P. K., HOLMGREN, N. H. \& BARNETT, L. C. (eds). 1990. Index Herbariorium, Edition 8. Part I. The herbaria of the world. Scientific Publications Department, New York Botanical Garden, 704 pages. ISBN 0-89327-358-9. Price (including post and package): US order $\$ 76.00$, non-US orders $\$ 78.00$. Discount for IAPT personal members. Clothbound.

Since 1952 Index Herbariorium has been the definitive directory of the public herbaria of the world. Edition 8, with 250 more pages than Edition 7, is the most comprehensive volume produced to date and provides fundamental information on 2639 herbaria in 147 countries. It includes the following data about most of the herbaria listed: address; affiliation; acronym; telephone, fax and cable numbers; CITES permit number; status; year it was founded; list of important collections; number of specimens; exchange available; name, telephone number and year of birth of the herbariums' curator, director and staff; periodical and serial works; associated garden; information about loans and exchanges procedures.

Orders and further information from: Index Herbariorium, Ed. 8, Scientific Publications Department, The New York Botanical Garden, Bronx, NY 10458-5126, USA. Fax: (212) 2206504. (Institutional IAPT members should contact Koeltz Scientific Books, PO Box 1360, D-6240 Koenigstein, Germany.) 